\title{
PERSEPSI ISLAM TENTANG PENDIDIKAN BAGI PEREMPUAN YANG BERKEADILAN GENDER
}

\author{
Andi Warisno \\ STAI An-Nur Lampung
}

\begin{abstract}
Social construction in society which proposed as superior is stereotype concept that has meaning woman as domestic workers and men as breadwinner at outside (public workers). The problem of inequality between women and men in employment area cause imbalance gender direct to reconstruction and reformulation of social system and religion which close to Islamic ideal ambition, that is justice. The key mission of Al Qur'an and As Sunnah is freeing humanity from anarchy, inequality, and injustice. In this case, if there is different interpretation based on justice principles and human rights, it should be revisited. Allah is Justice (al-'Adl), His scripture must right. The struggle of woman position (muslimah) is not enough only from their thoughts, making theory/concepts, but also needed collective effort from the result of study, investigation, social analysis, education and advocacy.
\end{abstract}

Keywords: Woman, Gender, Islam, Justice.

\begin{abstract}
Abstrak
Konstruksi sosial dalam masyarakat yang selama ini diteguhkan adalah konsep stereotipe tentang perempuan yakni sebagai pekerja rumah tangga (domestik) dan laki-laki adalah pencari nafkah/pekerja di luar rumah (publik). Permasalahan ketimpangan antara perempuan dan laki dalam wilayah kerja ini menimbulkan bias gender yang akan terus bergulir, mengarah pada rekontruksi dan reformulasi sistem sosial maupun keagamaan yang lebih mendekati cita-cita islam ideal yang sesungguhnya yaitu : keadilan. Sebab misi utama al-Qur'an dan as-Sunnah adalah untuk membebaskan manusia dari berbagai bentuk anarkhi, ketimpangan dan ketidakadilan. Jika ada penafsiran yang tidak sejalan dengan prinsip-prinsip keadilan dan hak-hak asasi kemanusiaan, maka penafsiran tersebut harus ditinjau kembali. Allah SWT Maha adil (al-'Adl), maka tidak mungkin di dalam kitab suci-Nya terkandung sesuatu yang tidak sejalan dengan prinsip-prinsip tersebut. Perjuangan posisi perempuan (muslimat) ini tidak cukup melalui pemikiran, pembuatan teori/konsep, namun juga diperlukan upaya kolektif yang merupakan paduan dari hasil studi, investigasi, analisa sosial, pendidikan serta advokasi.
\end{abstract}

Kata kunci: Perempuan, Gender, Islam, Keadilan.

\section{Pendahuluan}

Islam seringkali dikaitkan dengan diskriminasi terhadap perempuan. Kesan penindasan terhadap kaum Hawa ini diperkuat lagi dengan apa yang berlaku di sebahagian negara yang membawa nama Islam. Adanya larangan mufti Mesir pada tahun 50-an bahwa kaum perempuan tidak dibenarkan berpartisipasi dalam segala bentuk aktifitas umum dan membatasi diri dengan aktifitas dalam rumah saja. Selanjutnya tindakan Pemerintahan Taliban yang menafikan hak pendidikan bagi perempuan, dan pandangannya mengenai adanya hak wali untuk memaksa anak perempuannya untuk menikah dengan orang yang tidak dikenalinya di Pakistan, merupakan sebagian contoh yang 
menguatkan lagi kesan diskriminasi tersebut. Semua ini menimbulkan persoalan yang sangat kontroversi.

Secara lahiriyah umat Islam berhadapan dengan dua pilihan yang bertentangan (two opposing ends) yaitu antara konservatisme dan liberalisme. Akan tetapi pada hakikatnya dalam tradisi Islam terdapat alternatif ketiga yaitu jalan tengah atau al-wasatiyyah, meminjam istilah yang digunakan oleh alQaradawi. ${ }^{1}$ Jalan tengah yang dimaksudkan di sini meskipun tidak identik dengan penyebutan Islam moderat, tetapi tampaknya lebih dekat dan lebih pas dengan sebutan tersebut, terutama jika dihadapkan pada realita adanya kelompok Islam konservatif dan liberal. Golongan Islam moderat adalah golongan yang mengambil pendekatan yang sederhana dan seimbang antara pendekatan konservatif dan liberal.

Ketiga golongan di atas memiliki pandangan yang sangat berbeda dalam menanggapi persoalan gender. Dalam banyak perkara khilafiyyah, golongan moderat $^{2}$ mengambil pendekatan pertengahan di antara konservatif dan liberal/feminis. Sebagai contoh, ketika Islam menetapkan kewajiban hijab3, (bertudung, the veil) terdapat perbedaan pandangan di kalangan ulama. Kalangan konservatif memandang bahwa hijab harus dikenakan pada wajah, tapak tangan dan seluruh aurat perempuan. Golongan moderat berpendapat bahwa hijab tidak mencakup wajah dan pergelangan tangan, kerana disokong oleh dalil yang kuat dan pendapat mayoritas ulama. Perbedaan pendapat ini memberikan kelonggaran kepada perempuan untuk memilih salah satu pendapat yang dianggap betul.

Dalam banyak hal, pendekatan konservatif bersifat protektif bahkan terkadang dikatakan 'over protective', seperti terlihat pada sebahagian ulamaAfghanistan ketika zaman pemerintahan Taliban yang tidak membenarkan kaum perempuan mendapatkan haknya dalam pendidikan atas dasar peranan kaum perempuan yang menurutnya hanya terbatas di dalam rumah. Sedangkan bagi golongan moderat, pendidikan bukan saja merupakan hak, akan tetapi juga merupakan kewajiban bagi setiap Muslim tanpa melihat jenis kelamin. Oleh itu pendapat kelompok konservatif di atas hanyalah berdasarkan ijtihad subjektif ulama kerana baik nas al-Qur'an mahupun Hadis sama sekali tidak memberikan

1Pendekatan sederhana ini dipopularkan oleh Dr. Yusuf al-Qaradawi bersumberkan ayat al-Qur'an ummatan wasatan (al-Baqarah, 2:143) lihat: al-Qaradawi. Sanggahan Salah Tafsiran Islam (Kajang: Synergymate, 2004), hal. viii; al-Qaradawi, Min Fiqh al-Dawlah fi al-Islam. (Kaherah: Dar alShuruq, 1996), hal. 9 ; Al-Qaradawi. Al-Siyasah al-Shar'iyyah fi Daw al-Nusus al-Shari'ah wa maqasidiha (Kaherah: Maktabah Wahbah, 1998), hal. 30.

2Penulis memilih nama Islam moderat bagi golongan sederhana ini, meskipun sebagian penulis yang lain menyebutnya dengan istilah yang berbeda, misalnya golongan Islamis.UntukperbandinganmaknaistilahtersebutlihatFaridEsack, Qur'an,Liberation and Pluralism: an Islamic Perspective of Interreligious Solidarity against Oppression (Oxford: Oneworld, 1997), hal. xi.

${ }^{3}$ Ada penafsiran yang berbeda tentang hijab. Bagi golongan konservatif, hijab dimaknai niqab atau chador (Pakistan) dan abaya (Mesir). Sedangkan bagi golongan modernis hijab adalah tudung (headscarf). The veil dalam bahasa Inggris memberi makna lebih cenderung kepada niqab atau chador oleh itu tidak sesuai digunakan kalimat ini.

RI'AYAH, Vol. 01, No. 02 Juli-Desember 2016 
justifikasi. Perbedaan pendapat yang cukup tajam juga terjadi dalam masalah lain, seperti persoalan kepemimpinan publik (wilayah 'ammah), warisan dan sebaginya. Kompleksitas persoalan perempuan ini mendorong penulis untuk mengkaji sebagiannya dalam makalah ini. Pengkajian dalam makalah ini akan difokuskan di seputar perempuan sebagai subjek belajar dan pendidikan ditilik dari kacamata Islam.

\section{Sekilas Tentang Gerakan Kaum Feminis Muslim}

Istilah 'feminis Muslim' meskipun baru diperkenalkan dan digunaka sekitar tahun 1990-an, namun asas perjuangan dan pemikiran mereka adalah kesinambungan dari gerakan feminisme Barat yang telah dianuti dan diterima sebagai satu wadah untuk memperjuangkan hak-hak serta kepentingan perempuan. ${ }^{4}$ Margot Badran, seorangsarjana di Center for Muslim-Christian Understanding di Georgetown University, secararingkasmendefinisikanfeminis Islam sebagai"a feminist discourse and practice articulated within an Islamic paradigm."

Pada dasarnya, gerakan feminis muslim merasa mendapat mandat untuk memperjuangkan hak dan keadilan perempuan dari ajaran yang terkandung di dalam al-Qur'an. Definisi yang lebih jelas yang diberikan oleh kalangan Feminis sendiri, Azza M. Karam, ialah: "a one who adopts a worldview in which Islam can be contextualized and reinterpreted in order to promote concepts of equity and equality between men and women, and for whom freedom of choice plays an important part in expression of faith." 5

Di antara sarjana dan tokoh yang pernah menggunakan istilah tersebut di dalam penulisan mereka, sekaligus menyumbang dalam memperkenalkannya di dunia Islam adalah Afsaneh Najma badeh dari Ziba Mir-Hosseini dari Tehran, Mai Yamani dari Saudi di dalam bukunya Feminism and Islam pada tahun 1996 serta Yesim Arat dari Turkey. Mesir dikatakan sebagai tempat lahirnya Islamic feminism, terkenal dengan tokohnya Huda Shaarawi (1879-1947) yang mendirikan The Egyptian Feminist Unionpada 1923. ${ }^{6}$

Perlu disebutkan di sini, bahwa meskipun dasar dan asas pemikiran para pejuang keadilan perempuan itu sama, namun tidak semua secara terbuka mengatasnamakan diri mereka sebagai perjuangan Feminis Islam atau Feminis Muslim. Bagi sebagaian pelopor perjuangan gender ini, usaha mereka dalam menuntut keadilan sosial dan kesetaraaan gender merupakan intisari ajaran alQur'an. Usaha tersebutdigambarkansebagai 'projekpentafsiran Islam danpemahamansemulateks-teks al-Qur'an' serta 'women-centered readings of religious texts'.

4http://mediaguidetoislam.sfsu.edu/women/03_feminism.html

${ }_{5}^{5}$ Azza M. Karam, Women, Islamisms and the State: Contemporary Feminisms in Egypt, (London: Macmillan Press Ltd, 1998), hal. 5.

6Ibid.

RI'AYAH, Vol. 01, No. 02 Juli-Desember 2016 
Prioritas misi kebanyakan Feminis Muslim adalah rekonstruksi hukumhukum agama berkaitan dengan perempuan, terutama yang berkaitan dengan hukum keluarga. Mereka menilai dan menganalisa semula teks agama -alQur'an dan al-Sunnah- serta mentafsirkannya dengan perspektif yang berbeda dengan penafsiran klasik. ${ }^{7}$ Pendekatan yang mereka gunakan adalah berorientasikan perempuan. Dalam memahami teks tersebut, pandangan serta pengalaman mereka sebagai perempuan dijadikan asas pertimbangan. Hasilnya, muncullah beberapa pendekatan dan kelompok, seperti kelompok yang memberi fokus terhadap teks-teks al-Qur'an yang dipelopori oleh Amina Wadud, Rifaat Hassan dan Fatima Naseef, kelompok yang khusus menganalisis hadis Nabi, seperti Fatima Mernissi dan Hidayet Tuksal, dan kelompok yang mengaplikasikan pemahaman al-Qur'an (re-reading of the Qur'an) dalam hukumhukum Syariah seperti Aziza al-Hibri dan Shaheen Sardar Ali.

Secara umum, Feminis Muslim mengaplikasikan beberapa jenis pendekatan dan metodologi dalam membahaskan hukum-hukum berkaitan perempuan yang terdapat dalam teks-teks agama. Ini termasuk metodologi tradisional seperti ijtihaddan tafsir, serta beberapa metodologi yang melibatkan bidang ilmu yang lain seperti antropologi, sosiologi, sejarah, linguistik dan literary criticism. Para Feminis Muslim merasakan bahawa hukum kekeluargaan Islam perlu mengalami proses reformasi bagi mengurangkan skenario penguasaan lelaki (male domination). Mereka berargumentasi, perbedaan dan berbagaiversi undang-undang Islam di antara negara-negara Islam membuktikan undang-undang Islam sebenarnya sangat kuat dipengaruhi oleh keadaan sosiopolitik setempat, dan bukann divine injunctions. Menurutnya, ini membuktikan bahawa teks-teks agama boleh ditafsirkan dengan tafsiran yang berbeda, mengikut pemahamam atau pre-understanding masing-masing. Bahkan, argumentasi mereka diperkuat lagi dengan adanya perbedaan tafsir al-Qur'an di antara para mufassirin. ${ }^{8}$

Di antara argumen dasar bagi feminis Muslim adalah 'gender equality'kesetaraan dan kesaksamaan gender, yang diklaim merupakan ajaran pokok dan fundamental di dalam Islam. Golongan feminis Muslim menegaskan bahawa alQur'an sebagai kitab suci dan panduan utama bagi ummat Islam amat menekankan persamaan serta kesetaraan antara semua manusia, terutamanya antara lelaki dan perempuan. Ironinya, ini tidak berlaku dalam realiti kehidupan sosial ummat Islam sejak dahulu hingga sekarang. Bagi mereka, 'equality' yang di gariskan oleh Islam telah dipengaruhi dan diwarnai oleh ideologi dan amalan patriarchal. Bahkan dalam pandangan para feminis uslim, Fiqh (hukum-hukum hasil ijtihad para ulama) dan Syariah Islam juga tidak lepas dari unsur patriarki. Alasannya menurut mereka adalah para ulama' yang terlibat dalam proses

${ }^{7}$ Asghar Ali Engineer. The Qur'an, Women and Modern Society. (New Delhi: SterlingPublishers, 1999), hal. 4.

8Ibid., hal. 17.

RI'AYAH, Vol. 01, No. 02 Juli-Desember 2016 
kodifikasi hukum-hukum fiqh pada kurun ke 9 Hijrah terdiri dari para individu yang hidup dan bergelimang dengan pemikiran serta tingkahlaku patriarki. Kondisi ini menurut mereka menjelaskan sebab dan faktor mengapa sebagian hukum di dalam Syari'ah tidak mengaplikasi prinsip equality (persamaan) sebagaimana mestinya.

Menurut para feminis muslim, para penafsir al-Quran tidak secara komprehensif menafsirkan teks-teks kitab suci tersebut. Para mufassir banyak salah dalam menafsirkan al-Quran, karena menafsirkan sebagian dari ayat-ayat tidak secara keseluruhan. Banyak mufassir yang melebih-lebihkan patriarki yang ada dalam Al-Quran. Menurut mereka, al-Quran juga tidak menunjukkan bahwa pria lebih kuat daripada perempuan. Dari corak pemikirannya, pandangan para feminis muslim tidak berbeda dengan pandangan kelompok liberalis muslim. ${ }^{9}$

Para feminis muslim menilai bahwa memahami ajaran agama melalui penafsiran al-Qur'an sebagaimana yang ditafsirkan ulama salaf tidak sepenuhnya benar. Artinya kondisi sosial masyarakat tidak lagi seperti pada masa dulu. Bukan saja karena al-Qur'an harus diyakini berdialog dengan setiap generasi, tetapi juga harus dipelajari dan dipikirkan. Sementara hasil pemikiran (termasuk penafsiran) selalu dipengaruhi oleh beberapa faktor, misalnya kondisi pengalaman, ilmu pengetahuan, latar belakang pendidikan yang berbeda dari satu generasi ke generasi lainnya, bahkan antara pemikir satu dan pemikir lainnya pada suatu generasi.

Pandangan para feminis muslim di atas tampak agak berlebihan, serta terkesan tendensius dan tidak objektif. Setiapkali mereka menganalisis teks-teks keagamaan, baik al-Qur'an maupun Hadis, yang menyangkut persoalan gender tampak sekali seperti membawa misi memperjuangkan kaum perempuan. Akibatnya, pemaknaan atau penafsiran terhadap teks-teks keagamaan yang tidak sesuai garis perjuangan mereka, dikritik bahkan ditentang habis-habis.

\section{Pandangan Islam mengenai Perempuan}

Berbicara tentang Islam, berarti berbicara tentang al-Qur'an dan Hadis. Hal itu tidak lain karena Islam merujuk pada keduanya secara total. Dalam bahasa yang sederhana, apa saja yang dikandung oleh keduanya, itulah yang disebut Islam. Dengan demikian, Islam adalah keseluruhan ajaran yang dikandung dan digali oleh dan dari al-Qur'an dan Hadis. Bertolak dari sini, penulis dapat mengatakan bahwa yang dimaksud pandangan Islam mengenai perempuan di atas adalah pernyataan-pernyataan al-Qur'an dan atau hadis mengenai perempuan. Penulis tidak akan membahas semua ayat atau hadis nabi mengenai segala sesuatu yang menyangkut diri perempuan, karena hal itu sangat kompleks dan butuh pemahaman yang mendalam. Dalam tulisan ini,

${ }^{9}$ Bahrudin, Islam, perempuandanilmu, Makalah Teori Belajar PPs UNY tanggal 15 Agustus 2009 tidak diterbitan

RI'AYAH, Vol. 01, No. 02 Juli-Desember 2016 
penulis hanya akan menukil beberapa ayat dan hadis yang sering diperdebatkan, terutama oleh para aktifis feminim muslim.

Pada fitrahnya kaum perempuan merupakan sesuatu yang berbeda dengan laki-laki. Meskipun perbedaan secara fitrah tersebut tidak perlu dijadikan alasan untuk membeda-bedakan perlakukan antara kaum laki-laki dengan kaum perempuan.Islam mengajarkan umatnya untuk saling menghargai dan menghormati.Ada sekitar 30 ayat Al Quran yang mengacu pada kesetaraan antara perempuan dan laki-laki dan hak perempuan. Lebih lanjut, al Quran juga melarang paling tidak enam bentuk kekerasan terhadap perempuan yang lumrah terjadi di masyarakat Arab pada saat itu. ${ }^{10}$

Al-Qur'an telah menetapkan tugas yang seimbang bagi lelaki dan perempuan. Tugas ini diberikan sesuai dengan fitrah dan kemampuan masingmasing, berdasarkankepada fitrah semula jadi perempuan yang berbeda dengan lelaki. Dari segi fisikal, emosi dan psikologi hanya perempuan yang dapat menjalankan tugas keibuan dengan baik. Hal itu kerana dibandingkan laki-laki, perempuan cenderung lebih penyayang, lembut, cepat bertindak secara naluri dan instink keibuan dapat memenuhi tuntutan tugas dengan baik. Adapun kaum lelaki biasanya lambat bertindak dan mempertimbangkan sesuatu sebelum bertindak ditambah beberapa kecenderungan lain yang sesuai potensi bawaan sebagai pekerja keras dan terkadang kasar di luar rumah untuk memenuhi keperluan keluarga.

Bukanlah kerendahan perempuan dan kelebihan lelaki yang membuat perbedaan tugas tersebut akan tetapi fitrah semula jadi dan psikologi keduanya yang menjadi pertimbangan agar masing-masing tugas dapat diemban dengan baik. Karena itu tidaklah pantas dan bertentangan dengan fitrah, jika perempuan diperlakukan sama dengan laki-laki, seperti dalam masalah hak reproduksi atau dalam sebagian pekerjaan. Betapa tidak manusiawinya jika perempuan disuruh untuk melakukan pekerjaan kasar, yang membutuhkan tenaga besar, seperti menarik becak, menggali sumur atau jalan dan sebagainya untuk menggantikan peran suami, ketika suaminya sakit.

Islam telah bersikap adil kepada kedua pasangan, misalnya dengan memberikan tugas kepada lelaki untuk membiayai dan melindungi keluarga dan kepada perempuan tugas membesarkan anak (child bearing). Justeru yang tidak adil adalah memberikan kedua bidang tugas tersebut kepada perempuan yang dewasa ini banyak dialami oleh keluarga-keluarga yang bermasalah. Dari segi norma-norma yang dipegang oleh masyarakat juga jelas bahawa perempuan mengharapkan seorang lelaki yang bertanggung jawab dan memimpin keluarga bukan sebaliknya. Banyak aduan dibuat dari pihak perempuan yang mengadu suami mereka tidak membiayai hidup keluarga bahkan tugas tersebut terpaksa dilakukan oleh isteri seorang diri. Sebaliknya, tidak pernah terdengar ada

${ }^{10}$ Muhammad Fuad Abd al-Baqi, al-Mu'ajam al-Fahras li Alfadh al-Qur'an al-Karim, Bandung: Maktabah Dahlan, Indonesia, tth.

RI'AYAH, Vol. 01, No. 02 Juli-Desember 2016 
pengaduan yang menyalahkan isteri tidak memikul tanggung jawab memberi nafkah keluarga atau memimpin keluarga. Akan tetapi yang menjadi kebiasaan adalah isteri yang dipersalahkan kerana tidak menjalankan tanggungjawab membesarkan anak. ${ }^{11}$

\section{Kontroversi Sekitar Kelemahan Perempuan}

Kelompok Feminis Muslim tidak jarang yang menilai, Islam adalah agama yang mysagonist, dengan bukhti adanya beberapa hadis hadis yang menyatakan perempuan adalah lemah dari segi akal dan agama (naqisat al-'aql wa al-din). Mengenai hadis tersebut, golongan liberal dan feminis sekali lagi mencoba melihatnya secara atomistik tanpa melihat pada pesan hadis tersebut. Namun bagi kelompok moderat, kesahihan hadis tersebut tidak dapat dipertentangkan lagi kerana ia diriwayatkan dalam seluruh kutub al-sab'ah, yakni tujuh kitab induk di bidang hadis (Shahih al-Bukhari, Shahih Muslim,Musnad Ahmad, Sunan Abu Dawud, Sunan Nasa'i, Sunan al-Tirmidzi dan Sunan Ibn Majah) yang disetujui dan diakui otoritinya. Persoalannya, apakah benar hadis Rasulullah tersebut merendahkan martabat perempuan? Selengkapnya hadis tersebut bermaksud:

Dari Abu Sa'id al-Khudri berkata Rasulullah keluar pada pagi hari atau ...ke Musalla, beliau melalui sekumpulan perempuan dan berkata: "Wahai kaum perempuan bersedekahlah! Kerana aku melihat kalian penghuni neraka terbanyak". Mereka berkata: "mengapa wahai Rasulullah?" Beliau berkata: "kalian banyak mengutuk dan tidak menghargai kebaikan (suami) aku tidak melihat selain dari kalian orang yang kurang akalnya dan agamanya (naqisat 'aql wa din) yang dapat menghilangkan fikiran akal lelaki yang tegas". Mereka berkata: "wahai Rasulullah apakah kelemahan agama dan akal kami?". Beliau bersabda: "Bukankah kesaksian perempuan adalah separuh kesaksian lelaki?" mereka berkata: "ya". Beliau bersabda: "yang demikian itu adalah kerana kelemahan akalnya, bukankah apabila perempuan didatangi haid tidak melakukan solat dan puasa". Mereka berkata: "ya" beliau bersabda: "yang demikian itu adalahkelemahanagamanya". ${ }^{12}$

Kesahihan hadis ini tidak perlu dipertanyakan laki, baik dari segi matan mahupun sanad. Ia diriwayatkan oleh imam Muslim dari Ibn 'Umar, Abu Said dan Abu Hurairah; oleh Imam Ahmad dan Abu Dawud dari Ibn 'Umar; dan oleh Tirmizi dari Abu Hurairah. Namun, pertama sekali perlu digaris bawahi bahawa hadis tersebut tidak bersikap negatif terhadap perempuan, malahan hakikatnya

11SofyanHadi, Persepsi Islam TentangPendidikanPerempuan, Jurnal An-Nisa' Vol.2 No.2 Oktober 2009, PSG STAIN Jember, hal. 8-9

12Sahih al-Bukhari babal-Haidh no. 293; Sahih Muslim babal-Iman no. 114; Musnad Imam Ahmad, Musnad Ibn Umar no. 5091. Sunan Ibn Majah, babal-Fitan, no.3993;Sunan TirmizibabMa ja'a fi Istikmal al-Iman, riwayat Abu Hurayrah no. 2538; Sunan Abu Dawud, babziyadat al-Iman no. 4059 .

RI'AYAH, Vol. 01, No. 02 Juli-Desember 2016 
Rasulullah memberikan jalan keluar bagi kelemahan perempuan yang dapat menyebabkan mereka menjadi penghuni neraka. Jalan keluar yang dimaksudkan adalah dengan memperbanyakkan bersedekah, dan dalam riwayat lain pula disebutkan juga memperbanyakkan beristighfar. Di dalam hadis yang lain, ada dijelaskan maksud sedekah, yaitu dengan memperbanyakkan berbuat amal saleh. Dengan adanya jalan keluar ini maka kelemahan perempuan tersebut dapat diatasi dan ditutupi. Oleh karena itu, hadis ini bukanbermaksud merendahkan taraf perempuan, akan tetapi ia sebenarnya merupakan rahmat bagi kaum perempuan sendiri.

Perlu dijelaskan, adanya kelemahan ini tidak bermakna kaum perempuan adalah inferior dan kaum lelaki adalah superior kerana masing-masing telah diberikan oleh Allah Taala kelebihan dan kelemahan dalam bidang-bidang tertentu. ${ }^{13}$ Satu kenyataan yang perlu diingatkan di sini, ketika Rasulullah s.a.w. menjelaskan bahawa perempuan adalah naqisat al-'aql wa al-din, beliau tidak bermaksud kaum lelaki lebih sempurna akal dan agamanya. Kesempurnaan akal dan agama tidak bergantung kepada jenis kelamin, kerana jenis kelamin pada hakikatnya tidak menentukan ketajaman akal dan kesempurnaan agama. Sebaliknya, ketajaman akal dan kesempurnaan agama bergantung kepada sejauh mana masing-masing berusaha. Ini bermakna, dalam usaha ke arah kesempurnaan akal dan agama, kaum perempuan mempunyai hambatan yang lebih banyak atau beratdibanding kaum lelaki, meskipun keduanya berpotensi sama. Hambatan ini bukan dari segi biologi mahupun fisiologi, akan tetapi dari segi fitrah perempuan yang berlainan dari lelaki, di mana perempuan akan didatangi haidh yang dalam agama menjadi penghambat melakukan ibadah khusus, seperti shalat, puasa, haji, bahkan memegang mushaf.

Persoalan selanjutnya yang juga dimunculkan golongan Feminis adalah, hadis ini dengan jelas telah merendahkan kemampuan akal perempuan dengan adanya bukti lain yaitu kesaksian dua perempuan adalah sama dengan kesaksian seorang lelaki. Sebahagian ulama (konservatif) mengakui bahawa kesaksian perempuan lemah kerana kemampuan akal perempuan lebih rendah berbanding lelaki. ${ }^{14}$ Menurut penulis, walaupun secara lahiriyah, hadis di atas beberapa ayat al-Qur'an terkesan menunjukkan kelemahan perempuan, akan tetapi maksud sebenarnya dari hadis dan ayat tersebut tidak merendahkan. Ia hanya menjelaskan perbedaan yang sama sekali bukan bermakna diskriminasi.

Perihal QS. 2: 282 yang banyak dihujat kelompok feminim muslim, karena secara lahiriyah mengisyaratkan bahwa kesaksian dua perempuan sama dengan kesaksian seorang laki-laki, tampaknya ada kesalahpahaman dalam

${ }^{13}$ Lihat:QS., 4:32-34.

${ }^{14}$ Lihattulisan Muhammad 'Imarah, al-Islam waHuquq al-Insan (Jeddah: Markaz al-Rayah, 2005), passim.

RI'AYAH, Vol. 01, No. 02 Juli-Desember 2016 
penafsiran. ${ }^{15}$ Dalam ayat tersebut dijelaskan mengapa Allah menyuruh dua saksi perempuan, padahal untuk saksi laki-laki cukup satu. Al-Qur'an menjelaskan dijadikannya dua orang saksi perempuan, agar apabila satu saksi perempuan lupa mengenai materi persaksian, maka saksi perempuan yang satunya lagi mengingatkannya. Permasalahan yang muncul selanjutnya adalah, jika alasannya demikian, maka apakah perempuan lebih banyak lupa daripada pria?

Untuk menjawab permasahan tersebut, penulis hendak menukil sebuah laporan hasil penelitian kontemporer yang diadakan oleh para cendekiawan di Sidney, Australia, yang kesimpulannya disiarkan oleh jaringan televisi CNN dan BBC. Laporan penelitian itu menyebutkan bahwa kehamilan dapat mengurangi kekuatan memori seorang perempuan. Kondisi ini kadang-kadang berlanjut sampai seusai melahirkan. Kehamilan dapat sedikit mengurangi jumlah sel memori pada otak ibu yang hamil.16

Julia Henry, salah seorang peneliti perempuan dari Universitas New South Wales Sidney, Australia, memberikan komentarnya kepada CNN sebagai berikut: Bukti yang kami peroleh menyimpulkan bahwa daya IQ perempuan yang berkaitan dengan penyebutan unsur-unsur yang baru secara mendetail, atau aktifitas yang memiliki banyak tahapan, mengalami kegoncangan. Seorang perempuan hamil misalnya, ia lemah dalam menyebutkan nomor yang baru, tetapi dengan mudah ia akan mengulangi penyebutan nomor-nomor yang lama yang biasa ia pakai. ${ }^{17}$

Dengan bantuan Dr. Peter Rendel, Julia Henry berhasil mengukuhkan temuannya ini berdasarkan hasil analisis dari 12 penelitian yang berhubungan dengan kadar IQ sebelum dan sesudah melahirkan. Pada akhirnya, kesimpulan hasil penelitian tersebut menyebutkan bahwa perempuan hamil akan mengalami penurunan IQ-nya. Penurunan IQ tersebut terkadang berlanjut sampai setahun penuh pasca melahirkan. Bahkan mungkin lebih dari itu akibat adanya penurunan jumlah sel memori dan faktor-faktor lain yang belum ditemukan hingga sekarang. ${ }^{18}$

Tampaknya salah satu rahasia al-Qur'an memerintahkan persaksian dua orang perempuan dan seorang pria, sebagaimana yang disebutkan dalam QS. 2: 282, adalah seperti yang diungkap oleh hasil penelitian di atas, yakni bahwa karena faktor kehamilan, perempuan bisa menjadi pelupa, sehingga perlu ada yang mengingatkan, terlebih ketika ia menjadi saksi. Karena persaksian dalam Islam tergolong masalah yang sangat penting.

${ }^{15}$ Kelompok feminis muslim mempermasalahkan ayat yang artinya "Persaksikanlah dengan dua orang saksi laki-laki di antara kalian . Jika dua orang laki-laki tidak ada, maka (boleh) seorang laki-laki dan dua orang perempuan dari saksi-saksi yang kamu sukai. Supaya jika seorang lupa, maka seorang lagi mengingatkannya. (QS. 2: 282).

16Magdy Shehab, et. all., Ensiklopedia Mukjizt al-Qur'an dan Hadis, Jilid 2, Jakarta: Saptasentosa, 2008, hal. 134-135.

${ }^{17}$ Ibid.

${ }^{18}$ Ibid.

RI'AYAH, Vol. 01, No. 02 Juli-Desember 2016 
Dalam kajian-kajian kontemporer, perbedaan antara pria dan perempuan tidak terbatas hanya pada ciri-ciri fisik dan reproduksi saja. Namun perbedaan itu juga menyangkut banyak permasalahan seputar spesifikasi daya pikir dan perilaku. Sebagai contoh, anak laki-laki dan anak perempuan sedang bersamasama bermain. Anak laki-laki biasanya cenderung pada adu kekuatan, memanjat pepohonan, lari, balapan, sepak bola, dan jenis aktifitas lainnya yang memerlukan kekuatan fisik.

Berbeda dengan anak perempuan yang cenderung pada ketenangan, dan aktifitas olahgara ringan lainnya. Apabila pergi ke tempat-tempat permainan anak, di sana akan ditemukan, anak-anak laki-laki akan menuju permainan kuda-kudaan, mobil-mobilan, pedang-pedangan atau pistol-pistolan dan sebagainya. Sedangkan anak perempuan cenderung akan bermain boneka dan pengantin-pengantianan.

Anak perempuan yang baru lahir -berbeda dengan anak laki-lakimendongakkan matanya ke arah muka lebih tajam daripada mengarahkan pandangan ke arah peralatan yang bergerak. Kemudian ketika usianya mencapai tiga tahun, anak perempuan lebih sensitif dalam memahami berbagai perasaan dibanding anak laki-laki. ${ }^{19}$

Berbagai penelitian menunjukkan bahwa anak laki-laki lebih suka berselisih dibanding anak perempuan. Laki-laki sudah mulai berselisih di usia 13 tahun dan sering bermusuhan pada permulaan usia tersebut. Pertentangan sering terjadi saat perlombaan di berbagai level usia. Sementara itu waktu, anak perempuan sering menghabiskan waktu untuk permainan yang bersifat kerjasama atau kolaboratif, menjadikan mereka sebagai anak-anak dengan usia kurang dari enam tahun, yang mampu mengatur dan melakukan pengawasan. Berbeda dengan anak laki-laki yang bisa melakukan itu di tengah proses permainan mereka yang sangat keras.

Penulis mengungkapkan semua itu hanya sekedar untuk menjelaskan bahwa laki-laki dan perempuan itu memang berbeda. Hal itu terjadi semenjak jaman Adam dan Hawa. Perbedaan itu meliputi unsur fisik dan psikis. Namun perbedaan ini tidak berarti bahwa keduanya memiliki derajat yang berbeda. Dalam Islam derajat laki-laki dan perempuan itu sama. Laki-laki dan perempuan manapun yang beriman dan beramal shalih mereka akan diberi pahala dan kemulyaan yang sama oleh Allah. ${ }^{20}$

19Ibid., hal. 143

20Tentang kesetaraan derajat antara laki-laki dan perempuan dapat dilihat di berbagai tempat di dalam al-Qur'an, antara lain: QS.4:32, QS.16:97 dan, QS.40:40. Bahkan al-Qur'an menggunakan kata al-nisa, yang berarti wanita sebagai nama salah satu suratnya. Penggunaan nama tersebut adalah wujud pengakuan al-Qur'an terhadap peran strategis wanita, dan kalau kita mencermati isi surat tersebut, maka kita akan menemukan banyak ayat yang menunjukkan betapa Islam sangat menghormati harkat dan martabat kaum wanita.

RI'AYAH, Vol. 01, No. 02 Juli-Desember 2016 


\section{Persepsi Islam tentang Perempuan sebagai Subjek Belajar dan Pengetahuan}

Salah satu hadis yang sangat populer di kalangan masyarakat Islam adalah hadis yang artinya, "mencari ilmu adalah kewajiban bagi umat Islam, baik laki-laki maupun perempuan." Salah satu yang menarik dari hadis tersebut adalah digunakannya kata "faridhat" yang artinya kurang lebih sama dengan "kewajiban" atau "keharusan", yakni kewajiban atau keharusan bagi laki-laki dan perempuan muslim untuk menuntut ilmu (belajar). Mengapa hadis itu tidak menggunakan kata "haqqat" yang berarti, menuntut ilmu (belajar) adalah hak bagi laki-laki dan perempuan? Penggunaan kata faridhat memiliki implikasi yang berbeda dengan penggunaan kata haqqat. Penggunaan kata faridhat menunjukkan bahwa Islam memandang betapa pentingnya menuntut ilmu atau belajar bagi kehidupan kaum laki-laki maupun perempuan.

Dalam hadis lain disebutkan: "siapa yang menginginkan kebahagiaan dunia, maka ia wajib berilmu, dan siapa yang menginginkan kebahagiaan akhirat, maka ia wajib berilmu, dan siapa yang mengingingkan kebahagiaan keduanya (dunia dan akhirat), maka ia wajib berilmu ilmu." Dalam kajian Ushul Figh, kata "siapa" yang merupakan terjemahan dari lafadh "من", tergolong isim syarat, yang penunjukannya adalah umum, yakni meliputi laki-laki dan perempuan. Dengan demikian hadis itu dapat dimaknai: “siapapun orangnya, baik laki-laki maupun perempuan, kalau menginginkan kebahagiaan dunia, atau menginginkan kebahagiaan akhirat, atau menginginkan kebahagiaan dunia dan akhirat, maka ia wajib berilmu."

Dua hadis di atas hanyalah sekedar contoh yang menerangkan mengenai pentingnya menuntut ilmu (belajar) bagi laki-laki dan perempuan. Hadis-hadis yang senada dengan itu jumlahnya cukup banyak. Penulis hanya ingin menunjukkan, sesungguhnya Islam memandang bahwa mencari ilmu (belajar) adalah sangat penting bagi semua orang, baik laki-laki maupun perempuan. Karena itu, Islam tidak pernah membedakan jenis kelamin, dalam mewajibkan seluruh pemeluknya untuk mencari ilmu. Dari sini kita dapat menyatakan bahwa Islam memberikan hak bahkan kewajiban yang sama kepada laki-laki dan perempuan untuk belajar.

Dalam tulisan ini, penulis akan mendorong pembaca untuk mengambil sebuah "pandangan baru" mengenai beberapa kepercayaan yang populer tentang perempuan sebagai peserta didik. Penulis akan mengambil beberapa konseptualisasigender yang terakhir dan belajar untuk mengusulkan perspektif alternatif dalam berbagai setting. Tujuannya bukan untuk mendorong sebuah penekanan tentang perbedaan, tetapi lebih pada sebuah penghargaan jender sebagai sebuah aspek penting dari kehidupan kita dan pengetahuan.

Prespektif Islam tentang bagaimana pembelajaran perempuandan caracara perempuan memperoleh pengetahuan baru tampaknya tidak berbeda jauh dengan pandangan modern. Al-Qur'an maupun hadis memang tidak secara eksplisit menerangkan mengenai hal itu. Namun kita bisa mengambil

RI'AYAH, Vol. 01, No. 02 Juli-Desember 2016 
pandangan para tokoh muslim yang berusaha menggali semangat (roh) alQur'an dan hadis untuk mengungkap pandangan Islam tentang kecenderungan fitrah perempuan dalam belajar dan memperoleh pengetahuan baru. Sebagaian pakar Islam menyatakan "kaum perempuan selalu membentuk satu kelompok dalam memecahkan masalah apa saja secara bersama-sama." 21 Pandangan ini senada dengan pendapat para pakar dari dunia Barat yang menilai bahwa caracara belajar perempuan secara populer dikarakteristikkan sebagai bersifat kolaboratif dan empatik.22 Cara belajar perempuan yang dikarekteristikkan sebagai bersifat empatik tidak bisa dilepaskan dari sifat kolaboratif atau kerja sama tersebut. Biasanya sekelompok orang mau berkolaborasi karena adanya sikap empati diantara mereka. Sikap empati ini yang mendorong keinginan untuk berkolaborasi. Dengan demikian, dalam konteks ini pandangan Islam sama dengan pandangan modern.

Konsep lain dari dunia Barat tentang cara perempuan memperoleh pengetahuan baru dalah konsep pengetahuan terkoneksi diperkenalkan oleh para penulis cara perempuan memperoleh pengetahua, seperti Belenky, Clinchy, Goldberger, dan Trule, 1986, yang mungkin menjadi pemberitaan yang paling berpengaruh dalam dua dekade terakhir.23Pengetahuan yang terkoneksi digambarkan sebagai merangkul ide-ide baru dan berusaha memahami poinpoin pandangan yang berbeda. Pengetahuan terkoneksi dipertentangkan dengan pengetahuan yang terpisah, yang dikarakterisasi dengan mengambil sikap yang lebih menentang terhadap ide-ide baru dan mencari kekurangan-kekurangan dalam logika dan pemikiran. Pengajaran yang terkoneksi dimaksudkan untuk melawan gaya-gaya pendidikan tradisional yang menekankan pengetahuan dan agaknya, bertentangan dengan gaya belajar yang dipilih perempuan. Ide tersebut mempengaruhi desain banyak program pendidikan bagi perempuan, khususnya di pendidikan tinggi (Stanton, 1996). ${ }^{24}$

Dalam Islam, cara belajar terkoneksi, yang dikarakteristikkan sebagai cara belajar yang merangkul ide-ide baru sesungguhnya bukan hanya merupakan klaim perempuan, tetapi juga klaim laki-laki. Di kalangan ulama Indonesia, yang notabene kebanyakan laki-laki misalnya, sudah lama menerapkan kaidah "almuhafadhat 'ala al-qadim al-shalih wa al-akhdhu bi al-jadid al-ashlah," yang secara bebeas dapat diartikan "memelihara ide-ide lama yang masih bagus (relevan), dan mengambil ide-ide baru yang lebih bagus (lebih relevan) dengan perkembangan zaman". Yang ingin penulis katakan adalah bahwa pengetahuan terkoneksi tidak bisa hanya diatributkan kepada perempuan, tetapi juga dapat diartibutkan kepada laki-laki. Dalam pengertian ini, laki-laki dan perempuan tidaklah berbeda. Tetapi jika pengetahuan terkoneksi diartikan sebagai

${ }^{21}$ Magdy Shehab, et. al, op cit., hal. 162

22Sharan B. Merriam (ed.), The New Update on Adult Learning Theory, San Francisco, JosseyBass, 2001, hal. 37

${ }^{23} \mathrm{Ibid}$.

${ }^{24}$ Ibid.

RI'AYAH, Vol. 01, No. 02 Juli-Desember 2016 
pengetahuan yang diperoleh dari hasil hubungan atau interaksi antar manusia, maka dalam konteks ini perempuan memang lebih menonjol di bandingkan lakilaki. Pengetahuan terkoneksi dalam pengertian ini tidak bisa dilepaskan dari karakteristik perempuan yang cenderung melakukan kegiatan belajar secara kolaboratif. Dalam sistem pembelajaran kolaboratif akan muncul interaksi pemikiran di antara anggota kelompoknya. Interaksi pemikiran ini dapat memunculkan pengetahuan baru bagi para anggota kelompok yang notabene adalah perempuan.

Orientasi-orientasi perempuanmenuju hubungan manusia dihubungkanpada karakterisasi perempuan sebagai keyakinan subyektif, yang bersifat emosional. Dalam kaitan ini, para ilmuan menemukan bahwa perempuan menggunakan otak pada lapisan luar yang datar (cerebral cortex) dalam hal-hal yang berhubungan dengan memori dan emosi atau perasaan secara bersamaan. Oleh karena itu memori perempuan terpengaruh oleh emosi dan kejadian-kejadian yang berkaitan dengan emosinya. Sementara pada pria ditemukan bahwa pusat emosi dan pusat memori berada di dalam otak pada wilayah yang disebut hippocampus. Istilah ini untuk mengungkapkan sebuah lengkungan syaraf yang merupakan pusat memori. Kedua ujungnya adalah pusat emosi yang disebut buah otak (amygdale). Oleh karena itu perasaan perempuan dalam masalah emosional lebih sensitif daripada pria. ${ }^{25}$

Dengan bukti tersebut, ada kecenderungan perempuan untuk berbicara dan mengobrol, melihat sesuatu dari sisi lahiriahnya secara subjektif, dan mampu mengungkapkan emosinya dengan gambar, lebih mudah dan lebih baik daripada pria. Memori pria lebih sulit dipengaruhi oleh emosi, tidak seperti perempuan. ${ }^{26}$ Karena itu wajar jika pria tidak mudah mengungkapkan emosinya. Kondisi ini tampaknya terjadi karena pusat memori dan emosi pria terpendam dalam otaknya. Semua perbedaan ini menginsyafkan kepada kita tentang kesempurnaan syariat Allah yang mulia dan hikmah pensyariatannya yang melatarbelakanginya dalam menjaga dan memperhatikan perbedaan yang ada. Terkadang Allah membebankan suatu kewajiban hanya kepada pria, dan membentuk karaktek dan watak pria untuk memikul kewajiban tersebut. Terkadang Allah juga membebankan suatu kewajiban hanya kepada perempuan, dan membentuk karakter perempuan untuk memikul kewajiban tersebut. Namun dalam kontek belajar dan memperoleh pengetahuan, Allah membebankan kewajiban tersebut kepada pria dan perempuan, dan membentuk karakter keduanya sedikit berbeda untuk memikul kewajiban yang sama.

Kebenaran mutlak hanya milik Allah. Dialah Yang Maha Pencipta. Dia pula yang paling mengetahui kemaslahatan atau kebaikan bagi hamba-hambaNya. Allah berfirman:

${ }^{25}$ Magdy Shehab, et. al, loc. cit.

26Ibid., hal. 163

RI'AYAH, Vol. 01, No. 02 Juli-Desember 2016 
“Tuhanmu lebih mengetahui tentang kamu...." (QS. 17: 54)

\section{Membangun Diskursus dan Fiqh yang Berkeadilan Gender (Solusi Alternatif)} Islam memandang bahwa laki-laki dan perempuan diciptakan Allah SWT dalam derajat yang sama, oleh karena itu hubungan laki-laki dan perempuan adalah hubungan kesetaraan, tidak boleh terjadi ketidakadilan dalam hubungan tersebut, dan keduanya mempunyai hal yang sama dalam menentukan masa depan bersama. Karena Islam telah menekankan spirit keadilan dan keseimbangan (tawazun dalam berbagai aspek kehidupan).

Ternyata secara empirik dalam kajian fiqh (kitab-kitab fiqh), ditemukan beberapa kajian yang dipandang bias gender, yang dipandang cenderung kurang adil terhadap perempuan. Hal ini dipandang sebagai kenyataan yang menyimpang dari spirit Islam yang menekankan pada keadilan. Sejumlah kajian, diskusi, seminar digelar dimana-mana untuk menjawa mengapa terjadi ketidakadilan terhadap perempuan? Sungguh mencengangkan sekaligus menarik ketika diketahaui, bahwa "agama" telah terlibat dalam arus besar budaya yang tidak bersikap adil terhadap perempuan. Tanpa disadari pula, ternyata telah terjadi tarik menarik yang sulit dipisahkan antara system budaya dan "agama" yang memberikan kekuatan besar bagi terciptanya subordinasi dan ketertindasan kaum perempuan tersebut. Ketidakadilan ini, terutama berkaitan dengan persoalan relasi laki-laki dan perempuan di tengah-tengah pergumulan hidup dan kehidupan, baik dalam ruang domistik maupun publik. Ada kesenjangan dan ketimpangan antara identitas agama memberikan peran dan aktualisasi atas dasar-dasar kaum perempuan seperti diberikannya kepada kaum laki-laki, realitas social justru membatasi dan membelenggunya.

Kesenjangan seperti ini tentunya perlu dihilangkan melalui upaya-upaya intelektual yang kritis dan menerobos terhadap teks-teks keagamaan yang dijadikan pedoman. Dalam istilah yang popular kita perlu melakukan reinterpretasi dan rekonstruksi terhadap pembangunan pemikiran keagamaan dalam konteks social sekarang27.

Terdapat tiga bidang masalah yang menjadi halangan terciptanya "hubungan gender" yang lebih adil yaitu bidang yang berkaitan dengan teologi (pandangan agama), kebudayaan (persepsi masyarakat) dan politik ${ }^{28}$. Berikut penjelasannya :

\section{Bidang Teologi}

Terdapat penafsiran keagamaan terhadap ayat atau hadist yang tidak sesuai dengan prinsip keadilan gender, sebaliknya malah bias laki-laki. Sejumlah

27Husen Muhammad, Figh Perempuan, LKiS, Yogyakarta: hal. xxiv

28Saifuddin, ParadigmaBaruDalamKajianFighBerkeadilan Gender, Jurnal al-Adalah STAIN Jember Vol.5 No.2 Agustus 2002, hal 13-14

RI'AYAH, Vol. 01, No. 02 Juli-Desember 2016 
besar ulama memandang bahwa laki-laki memang menempati posisi superioritas atas perempuan. Laki-laki lebih unggul dari perempuan. Kesimpulan ini dihubungkan dengan QS. An-Nisa ayat 34 dan Hadist "Lam Yafliha Qaumun Wallau Amarahum Imra'atan".

Tokoh-tokoh utama yang menjadi panutan kaum muslimin diseluruh dunia, seperti Imam Malik, Imam Syafi'I, Imam Ahmad dan Al-Mawardi, ketika membicarakan kekuasaan kehakiman sebuah kekuasaan dalam wilayah publik mereka mempersyaratkan jenis kelamin laki-laki untuk jabatan ini. Menurut mereka kekuasaan kehakiman diperlukan kecerdasan pikiran prima. Criteria ini hanya dimiliki oleh laki-laki. Sementara tingkat kecerdasan dan intelektualitas perempuan di bawah kecerdasan laki-laki. Dan laki-laki berada di wilayah publik, sementara perempuan di wilayah domestik.

\section{Bidang Kebudayaan}

Terdapat apa yang disebut kebudayaan patriarkhi, yaitu kebudayaan yang menempatkan peran laki-laki melakukan apa saja dan menentukan apa saja, disadari atau tidak. Sebaliknya kaum perempuan berada pada posisi subordinat yakni tunduk pada laki-laki. Perempuan juga dianggap hanya layak berada di wilayah domistik, sesuai dengan pandangan perempuan sebagai teman belakang atau di balik wilayah publik. Hal ini biasanya disimpulkan dari ayat 33 surat al-Ahzab.

\section{Bidang Politik}

Terdapat praktek-praktek politik mendiskriminasikan perempuan. Di setiap instansi formal, kehadiran perempuan sangata marginal. Akibat ketidakterwakilan perempuan dalam pusat-pusat pengabdian keputusan itu adalah bahwa "isu-isu yang menjadi perhatian perempuan sering tidak mendapatkan perhatian di dalam perdebatan-perdebatan politik". Perempuan hanya menjadi obyek dari system politik yang dibangun secara sepihak oleh kaum laki-laki ${ }^{29}$.

Dalam pandangan mayoritas ahli fiqh konservatif selama ini, peran politik dalam arti amar ma'ruf nahi mungkar, laki-laki dan perempuan memang diakui sebagai memiliki hak dan kewajiban yang sama. Akan tetapi dalam arti politik praktis yang di dalamnya diperlukan pengambilan keputusan yang mengikat (al-Wilaya al-Multazamah) menyangkut masyarakat luas, seperti pengambilan keputusan dalam pengadilan (menjadi hakim) dalam lembaga legislative dan eksekutif atau kekuasaan besar/publik (al-Wilaya al-Udzma), tugas-tugas ini menurut kebanyakan ulama tidak dapat diperlakukan secara sama $^{30}$. Ingat rekomendasi konfrensi Islam Indonesia (KUII) tentang keharusan posisi presiden dan wakil presiden di jabat oleh pria. Dan dilarang di jabat oleh wanita.

${ }^{29}$ Said Aqil Munawwar, Loc. It., hal. 162

${ }^{30}$ Husen Muhammad, Loc. It., 141

RI'AYAH, Vol. 01, No. 02 Juli-Desember 2016 
Demikian juga fatwa yang dikeluarkan oleh Universitas Al-Azhar tahun 1992, misalnya menyebutkan : "Syariat Islam melarang kaum perempuan menduduki jabatan-jabatan yang meliputi kekuasaan-kekuasaan umum (publik). Yang dimaksud kekuasaan umum dalam fatwa di atas adalah kekuasaan memutuskan/memaksa (al-Sultanah al-Multazamah) dalam urusan-urusan kemasyarakatan (al-Jama'ah), seperti kekuasaan membuat Undang-undang (legislatif), kekuasaan kehakiman (yudikatif) dan kekuasaan melaksanakan Undang-undang (eksekutif) (Lajnah Fatwa bi al-Azhar),

Sedangkan untuk mengatasi tiga masalah di atas diperlukan upaya terusmenerus untuk : 1) Menafsirkan ulang beberapa nuktah dalam pemahaman keagamaan; 2) Untuk melihat kembali secara kritis paham-paham kebudayaan yang bias laki-laki (kebudayaan patriarkhi); 3) Untuk merombak praktek-praktek politik yang mendiskriminasikan perempuan. ${ }^{31}$

\section{Penutup}

Kesetaraan gender antara pria dan perempuan merupakan salah satu isu yang hingga sekarang masih hangat untuk dibicarakan. Ketika isu ini diseret ke dalam ranah agama, maka muncul anggapan miring dari kalangan tertentu yang tidak setuju dengan doktrin agama yang dianggap tidak berimbang dan tidak adil dalam memandang persoalan ini. Berkaitan dengan ini, Islam sering dihujat, baik oleh kalangan non muslim maupun oleh kalangan muslim, terutama yang menganamakan kelompok pejuang hak asasi manusia dan pejuang kepentingan kaum perempuan, yang kadang kala tidak mewakili aspirasi kaum perempuan itu sendiri. Ironisnya, para penghujat Islam ketika melakuka hujatan sering didasarkan pada perilaku dan pendapat sekelompok ulama tertentu yang pendapat-pendapatnya dianggap merendahkan kaum perempuan.

Islam menerangkan bahwa secara fitrah pria dan perempuan memang berbeda. Perempuan haid dan melahirkan misalnya, sedangkan pria tidak. Sebaliknya pria berkarakter keras, sedangkan perempuan berkarakter lembut. Singkatnya, secara fisik maupun psikis, keduanya memang berbeda. Akan tetapi, Islam sangat menjunjung tinggi harkat dan martabat kedua kelompok manusia yang berjenis kelamin berbeda tersebut. Dalam banyak ayat dan hadis Nabi diterangkan bahwa hak dan kewajiban pria dan perempuan seimbang. Salah satunya adalah hak dan kewajiban dan menuntut ilmu atau dalam belajar. Pria dan perempuan dikenakan kewajiban yang sama. Dalam aktifitas keagamaan lainnya keduanya dibebani kewajiban yang sama. Bahkan dalam beberapa hadis kaum perempuan sering disebutkan lebih mulia daripada pria. Ingat ketika Rasulullah ditanya oleh seorang sahabat tentang siapa orang yang paling berhak untuk dipergauli dengan baik. Beliau menjawab "ibumu" sebanyak tiga kali berturut-turut, baru kemudian jawaban yang keempatnya adalah "bapakmu". 
Dengan demikian sangat tidak beralasan jika dikatakan bahwa Islam memuliakan pria dan merendahkan perempuan.

\section{Daftar Pustaka}

Ahmed, Laela, Islam dan Gender, terj. MS Nasrullah, Lentera: Jakarta, 2000.

al-'Aqqad, 'Abbas Mahmud, ,al-Mar'ah fi al-Qur'an Beirut: Dar al-Kitabal-'Arabi, 1969.

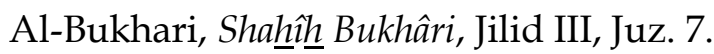

Ali, Ahmad Haidlor, "Kesetaraan Gender dan Pemberdayaan Perempuan di Pondok Pesantren, Studi Kasus di PP Seblak Jombang Jawa Timur, dalam Jurnal Penelitian Agama \& Kemasyarakatan Penamas, No. 36, Th. XIII, 2000.

Al-Qardhawi, Yusuf, Min Figh al-Dawlah fi al-Islam. Kaherah: Dar al-Shuruq, 1996. al-Sha'rawi, Muhammad Mutawalli, al-Mar'ah fi al-Qur'an al-Karim Kaherah: Maktabah al-Sha' rawi, 1990.

Badawi, Jamal, The Status of Woman in Islam (Riyad:World Assembly of Muslim Youth, 2000.

Badran, Margot dan Miriam Cooke, Opening the Gates: A century of Arab Feminist Writings. (ed.) London: Virago Press, 1990.

Bahrudin, Islam, perempuan dan ilmu, Makalah Teori Belajar PPs UNY tanggal 15 Agustus 2009 tidak diterbitan, 2009.

Departemen Haji dan Wakaf Saudi Arabia, 1413 H., Al-Qur'an dan Terjemahnya, Madinah: Komplek Percetakan Al-Qur'an Khadim al-Haramain asySyarifain Raja Fahd.

Dhofier, Zamaksyari, Tradisi Pesantren Studi Pandangan Hidup Kyai, Jakarta: Rajawali Press, 1982.

Engineer, Asghar Ali, The Qur'an, Women and Modern Society,New Delhi: SterlingPublishers, 1999.

Esack, Farid, Qur'an,Liberation and Pluralism: an Islamic Perspective of Interreligious Solidarity against Oppression, Oxford: Oneworld, 1997.

Fakih, Mansoer dkk., tth., Membincangkan Feminisme Diskursus Gender Perspektif Islam, Surabaya: Risalah Gusti.

Hadi, Sofyan, Persepsi Islam TentangPerempuan, dalamJurnalAnnisa Vol. 2 No.2 Oktober 2009. PusatStudi Gender (PSG) STAIN Jember, 2009.

Jane Smith and Yvonne Haddad, Eve: Islamic Image of Woman" in Women and Islam ed. by Azizah al-Hibri, Oxford: Pergamon Press, 1982.

Karam, Azza M., Women, Islamisms and the State: Contemporary Feminisms in Egypt, London: Macmillan Press Ltd, 1998.

Kurzman, Liberal Islam: A Source Book, London: Oxford University Press, 1998.

Mauleman, Hendrik, Perempuan Islam Indonesia dalam Kajian Tekstual dan Konstektual, Jakarta: INIS, 1993.

Mawdudi, Purdah and The Status of Women, Lahore: Islamic Publication, 1987.

Mernissi, Fatima, "Virginity and Patriarchy", in Women and Islam ed. By Azizah al-Hibri, Oxford: Pergamon Press. 1982.

Merriam, Sharan B. (ed.), The New Update on Adult Learning Theory, San Francisco, 2001.

Mosse, Julia Cleves, tth., Gender and Development, terj. Hartian Silawati, Cet. I Yogyakarta: Prakarsa

RI'AYAH, Vol. 01, No. 02 Juli-Desember 2016 
Muhammad Izzat Darwazah, tth., al-Mar'ah fi al-Qur'an wa al-Sunnah Beirut: alMaktabah al-Asriyyah

Muhsin, Amina Wadud, Qur'an and Woman, Kuala Lumpur: Fajar Bakti, 1992.

Muthahari, Murtadha, The Right Of Women In Islam, Teheran: Wofis, 1961.

Qutb, Sayyid, Fi Zilal al-Qur'an, Kaherah: Dar al-Shuruq, 1997.

Rahman, Abdur, Women in the Qur'an and The Sunnah,London: Taha Publication, 1988.

Subhan, Zaitunah, Tafsir Kebencian Study Bias Gender Dalam Al-Quran, Yogyakarta: LKiS, Yogyakarta, 1999. Perempuan Dan Gender Dalam Islam Akar-akar Historis Perdebatan Modern, Lentera: Jakarta, 1992.

Analisis Gender $\mathcal{E}$ Transformasi Sosial, cet. II, Yogyakarta: Pustaka Pelajar, 1997.

Sugeng S., "Konsepsi Gender Dalam Perspektif Islam", dalam Jurnal Ilmu Pengetahuan Agama Islam, No 58, Yogyakarta: IAIN Sunan Kalijaga, 1995. 